\title{
The Mediating Effects of Place Satisfaction and Support for Community: An Evaluation of the Performance of Small and Medium Tourism Enterprises in Bangladesh
}

\author{
Mahmoda Akter*, Md. Abdul Alim, Rubaiyat Shabbir, \\ Md. Borak Ali, Jee Teck-Weng and Jati Kasuma
}

\begin{abstract}
Manuscript type: Research paper

Research aims: This study aims to understand the impact of place identity on the performance of small and medium tourism enterprises (SMTEs). It also examines how place satisfaction and support for community mediate the relationship between place identity and the performance of SMTEs.

Design/Methodology/Approach: This study focusses on the tourism industry of Bangladesh. Data comprise of 215 small and medium enterprises involved in tourism. Analysis is conducted using the partial least squares-based structural equation modelling (PLS-SEM).

Research findings: Results suggest that place identity is related positively to place satisfaction, support for community, and firm per-
\end{abstract}

\footnotetext{
* Corresponding author: Mahmoda Akter is a Master student at the Department of Marketing, University of Rajshahi, Bangladesh. Email: m.papree18ru@gmail.com

Md. Abdul Alim is an Assistant Professor at the Department of Marketing, University of Rajshahi, Bangladesh. Email: m_alim@ru.ac.bd

Rubaiyat Shabbir is a Lecturer at the Department of Tourism and Hospitality Management, Bangabandhu Sheikh Mujibur Rahman Science and Technology University, Bangladesh. Email: rshabbir10@gmail.com

Md. Borak Ali, is a Professor at the Department of Marketing, University of Rajshahi, Bangladesh. Email: borakali@yahoo.com

Jee Teck-Weng is Senior Lecturer at the School of Business, Faculty of Business Design and Arts, Swinburne University of Technology, Malaysia Campus. Email: tjee@swinburne.edu.my Jati Kasuma is an Associate Professor at the Faculty of Business and Management, Universiti Teknologi Mara Malaysia, Sarawak Branch. Email: jati@uitm.edu.my
}

https://doi.org/10.22452/ajba.vol13no2.2 
formance. Surprisingly, support offered by the firm towards the local community did not contribute to firm performance. In this study, only place satisfaction plays a mediating role between place identity and firm performance.

Theoretical contribution/Originality: This study expands on existing literature by providing empirical evidence on the factors that could affect the performance of SMTEs' tourism business, in the context of Bangladesh. The inconsistency of the relationship between place identity and firm performance may be related to place satisfaction.

Practitioner/Policy implication: The findings can be useful for SMTEs, investors, travel agents as well as other stakeholders.

Research limitation/Implication: Since this study is focused on the Bangladesh tourism sector alone, the results may not be generalised to other countries.

Keywords: Place Identity, Place Satisfaction, Support for Community, Firm Performance, Bangladesh and Tourism

JEL Classification: M3

\section{Introduction}

Tourism is one of the fastest growing industries in the world (Daniloska \& Hadzi Naumova-Mihajlovska, 2015; Indriastuti, Kasuma, Saida Zainurrosalamia, Darma \& Sawangchai, 2020). This industry contributes significantly to the economic growth and social improvement of a country, where it creates employment opportunities for 292 million people (WTTC, 2018). Considering its capacity to generate millions of jobs globally, it is not surprising that tourism plays a considerable role in distributing wealth, and developing the economy of a country, particularly for emerging nations. It has been reported that the world tourism industry contributes a total of USD8.3 trillion to the global economy which is equal to 10.4 per cent of the world's GDP for the year 2017. Nonetheless, despite the immense growth opportunities provided by the tourism industry, the country of Bangladesh has failed to reap maximum benefits from this industry. Instead, a frustrating scenario of the country's tourism industry is persisting (Karim, 2014). Bangladesh possesses a large number of tourist spots, exquisite natural sights, pleasant environment and weather, but the country has not achieved much success in utilising her tourism spots and in attracting tourists, as compared to neighbouring countries Malaysia, Thailand, India and China. Although this figure was anticipated to increase, the industry's 
contribution to GDP of Bangladesh (4.4\%) was still considered low. Given this scenario, it is imperative to investigate how the performance of firms in the tourism sector could be enhanced. More effective efforts and new formulation of strategies are required so as to fully develop the tourism industry of Bangladesh.

As is visible in most countries, small and medium enterprises (SMEs) are the mainstay of the country; they also serve as one of the economic engines of the nation. In particular, the small and medium tourism enterprises (SMTEs) of Bangladesh also serve the same purpose for the tourism industry (Getz, Carlsen, \& Morrison, 2004). The overwhelming pre-eminence of small-scale entrepreneurships is one of the distinguishing characteristics in the world's tourism industry (Rogerson, 2005). The growth of tourism in the Asia-Pacific region is also a consequence of the emergence of the SMTEs (Chang, 2011). This shows that the performance of SMTEs is a critical factor for the subsistence and success of tourism destinations (Hallak, Brown, \& Lindsay 2012). Among businesses considered to be under the umbrella of the SMTEs are tour operators, hotels and accommodation, traditional services, handicrafts, and souvenirs. Being a small and medium scale business, such businesses are arguably, more responsive to market demands, since they are characterised as having more adaptability and flexibility. Nevertheless, the challenge of having a good business performance is a common obstacle faced by firms especially in times of survival.

Literature (Hallak et al., 2012, 2013; Hallak, Assaker, \& Lee, 2014; Ramkissoon, Smith, \& Weiler, 2013) indicates that few studies have been conducted to investigate the role of the SMTEs in the tourism sector, and the underlying factors that could contribute to their performance. These studies noted that SMTEs which provided support for the local community were able to achieve a higher level of business performance because those firms which engaged in corporate philanthropy were perceived to be socially responsible corporate citizens. They were able to offer various potential benefits including having workers who feel a sense of satisfaction working with them. Using the case study approach, Schilar and Keskitalo (2018) found that place identity may be a factor that stimulates and promotes successful tourism activities. This would eventually lead to good business performances for the SMTEs. However, this was noted only in the context of Sweden. There has been little research done on developing countries, despite the fact that factors such as place identity, and support for community have significant impacts on business performances. Moreover, most existing 
studies had been qualitative in nature, with none making any attempt to investigate how the relationship between these variables may be affected by the intervening variable (Islam \& Carlsen, 2016). Expanding on the previous empirical works of Hallak et al. (2012), the current study aims to incorporate place satisfaction as a mediator between place identity and business performance. In the existing literature (Ramkissoon et al., 2013), place identity has been noted to be an important predictor for place satisfaction, where place satisfaction increases with place identity. Owners of the tourism businesses who have a sense of belonging, and who also feel bonded by the tourism place may develop a positive perception of the place. Being accustomed to the place, they may value the place highly. The positive perceptions may, in turn, lead to their tendency to invest their resources so as to enhance the place as a tourism spot, which eventually increases firm performance. The lack of including all these constructs into a comprehensive framework, which can empirically be tested on the SMTEs within the context of Bangladesh, has thus motivated the present study. This study specifically aims to examine the impact of place identity on firm performance through the mediating variables of support for community and place satisfaction.

The remainder of this paper is structured as follows: Section 2 presents the background of the tourism industry in Bangladesh, the theoretical background, and the hypotheses development. Section 3 describes the methodological approach while Section 4 reports on the findings. Section 5 outlines the discussions and Section 6 highlights the conclusion and implications of the study.

\section{Literature Review}

\subsection{Bangladesh and its Tourism Industry}

Bangladesh is a developing country which is located in the north eastern part of South Asia. The country is recognised for its poor living conditions, continuous political instability, and as a zone that is prone to natural disaster. The World Bank report of 2019 acknowledges that over 40 per cent of its population are living under the poverty line, with majority of them involved in agriculture and garment industry. The United Nations World Tourism Organization (UNWTO) has attempted to develop a global agenda to support tourism as an approach to alleviate poverty within developing countries such as Bangladesh (Islam \& Carlsen, 2016). As a consequence of this, Bangladesh is considering the 
tourism industry as a fast track catalyst for its economic development so that its economic sector can comprise a total GDP of 4.4 per cent, as of the year 2019.

Cox's Bazar of Bangladesh appears to be one of the more popular tourist destinations that has attracted millions of tourists annually (Ray, 2019). This is not surprising since Cox's Bazar is the most beautiful, unbroken and longest sea beach in the world. The popularity of Cox's Bazar as one of the tourism destinations in Bangladesh appears to be leading the country towards a positive development of infrastructure. For instance, a better road network connecting the tourism destination to the main city has been developed, and an airport has been built to ease the transportation and logistics of international tourism. These two developments are indicators of a socio-economic development that has been spurred by the tourism activities in Cox's Bazar. The increasing presence of tourists in this region has also led to the establishment of wholesale traders, retail shops, accommodation facilities, restaurants and food, all of which provide a variety of products and services to the tourists. This scenario serves as the window of opportunity for the local communities, one of which is to get involved in the SMTEs.

\subsection{Place Identity Theory}

The current study uses the theory of place identity, which was developed by Proshansky, Fabian and Kaminoff (1983) as a theoretical basis. This theory explains the relationship that occurs between people and place, where place comprises both the physical and social environment. Place has been defined as the central reference point of the human existence (Relph, 1976), and people search places where they feel safe, secure and comfortable, and belong to (Hidalgo \& Hernandez, 2001). The natural settings of a particular place help people to find ways to develop their sense of identity, with its unique or distinct nature, different from other places (Budruk, Thomas, \& Tyrell, 2009; TwiggerRoss \& Uzzell, 1996). Individuals then develop a sense of self identity through the assimilation and acceptance of a commonly shared set of beliefs, rules, values, and expectancies of the place (Proshansky et al., 1983). The theory of place identity also argues that place identity is more than just a place attachment. It is a substructure of the individual's self-identity as well as his/her cognitive system. Like any other cognitive systems, place identity influences what people see, think, and feel with certain interactions with the physical world. This can be 
modified throughout the life of an individual, thus the places where people live can become an unquestionable part of their sense of self (Relph, 1976).

The level of the individual's place identity influences his/her selfidentity as a substructure of the individual's self-identity (Proshansky et al., 1983). Place identity shapes the individual's cognition, attitude, emotion, motivation, social role and behaviour toward the physical setting and community. Furthermore, the recognised function of placeidentity implies that individuals who spend their formative years in certain physical settings for long periods can derive satisfaction from these settings. Therefore, place identity directly influences the individual's self-identity, social-identity, attitude and behaviour towards the local community, henceforth their derived satisfaction. This theory has been used in more recent studies like Grey and O'Toole (2020). It was Proshansky et al. (1983) who noted that place identity can be used to predict place satisfaction. Therefore, the logical standpoint of the theory of place identity and its broad acceptance was employed as the theoretical foundation for this study.

\subsection{Hypotheses Development and Research Framework}

Identity is a set of meanings attached to an individual; it serves as a reference for guiding his/her behaviour (Stets \& Biga, 2003). Identity is developed through the interaction of memories, personal distinctiveness, and self-efficacy. In the context of tourism, Gu and Ryan (2008) highlighted that residents would be more likely to favour tourism if they perceive that tourism development is consistent with their place identity. A bond between a resident and a place would enable him/her to differentiate himself/herself from people of other places. A sense of bonding will help the individual(s) to manage their fears and anxieties, and to meet and cope with changing circumstances well. They would have a higher belief in their capabilities, and so be more willing to mobilise their resources, and take various courses of actions to meet the given situational demands (Chen, Wang, \& Xu, 2017).

Based on the above principle, it is expected that the owners of SMTEs would be more likely to attain higher business performance when the place of tourism is consistent with their identity. This is because as business owners of a small and medium scale, they would have to face numerous challenges and uncertainties in running the dayto-day business due to poor resources. Tasks such as developing new 
products, exploring new market opportunities, building innovative environment, negotiating businesses, initiating relationships with investors could be daunting challenges for the SMTEs, particularly if they have low self-efficacy in dealing with such circumstances (Hallak et al., 2012). Individuals would feel an extreme challenge to perform their best when doubts have been cast on their own abilities. Nevertheless, the negative effect of low self-efficacy can be reduced if they have a bonding and attachment with the place of tourism. With high levels of confidence, they would have higher levels of interest, motivation, and perseverance, thereby increasing their own as well as their businesses' performance (Hmieleski \& Corbett, 2008). Based on these arguments, it is postulated that:

\section{$\mathrm{H}_{1}$ : Place identity is positively related to SMTEs' performance.}

Place satisfaction is deemed as the utilitarian value of a place which meets certain basic needs. It is viewed as a multidimensional judgment of the perceived quality of a setting, including the fulfilment of the individual's needs for a particular physical characteristic of a place, and the social dimensions that it serves (Stedman, 2002). Several studies (Fleury-Bahi, Felonneau, \& Marchand, 2008; Ramkissoon et al., 2013) have indicated that place satisfaction could be influenced by place identity. These studies claimed that respondents with a strong sense of attachment with the place, were more likely to experience satisfaction. In the context of this study, it is argued that the sense of belonging and being identified with the place, and the feeling of neighbourhood residency contributes to the definition of the owners of the SMTEs who would then have a positive evaluation of the people and the place. A strong sense of psychological involvement in the daily living, accompanied by favourable relationships with the local people would also cultivate place satisfaction (Fleury-Bahi et al., 2008). Place satisfaction is important for sustaining the tourism destination. Owners who are satisfied with the place would be more likely to invest their resources in the long-term performance of the destination. In other words, place satisfaction would be translated into firm performance. Based on these, it is postulated that:

$\mathrm{H}_{2}$ : Place identity is positively related to place satisfaction.

$\mathrm{H}_{3}$ : Place satisfaction is positively related to SMTEs' performance.

$\mathrm{H}_{4}$ : Place satisfaction mediates the relationship between place identity and SMTEs' performance. 
A community is described as a group of people with some shared elements which vary from situations to situation, such as living in a particular place, interest, beliefs or values (Obst \& White, 2005). Alternatively, a community refers to the set of people who live in the place in which owners of the SMTEs operate their businesses. Situations where businesses have commitment towards their community, tend to support the local community. This has been described as community citizenship. Support for community is a multi-dimensional construct comprising business commitment, business support, and personal leadership in the community (Besser, 2003).

As SMTEs' owners are often bonded to the town and its people, these owners are often influenced by their level of place identity when deciding to provide support for the community (Hallak et al., 2012). Although they could be restricted by limited funds or resources in giving community support, they would be willing to engage and participate in the community activities. They would feel directly responsible for their communities since these communities are considered as a type of "extended" family. They all share the belief that their present businesses contribute to the community, hence they expect to benefit from the strong and healthy community in the long-term. Moreover, their public relationship with the community as a result of their philanthropic would also enhance their public image, thereby accelerating business success. This practice indicates that the reciprocal relationship between businesses and community is a validated rationale for improving long-term business performance. Besides that, the level of support that businesses provide to their communities may also positively influence their business performances (Miller \& Besser, 2000).

Although businesses can be conducted anywhere within the premise of the tourism destination, the success of the businesses would very much depend on the unique environment presented by the community, and their internal characteristics. The economic and social profits gained can simultaneously lead to sustainable marketplace performance. Social profits include opportunities for employees to become emotionally committed, thereby enhancing the quality of life for both employees and customers. These activities include raising money for charitable causes, responding to community crises, and offering donations in terms of money, time, and products to the local non-profit organizations. This practice indicates that businesses and communities who work together for mutual gains are more successful (Besser \& Miller, 2004). Previously, Hallak et al. (2013) had advocated that support for 
community has a positive influence on SMTEs' performance. However, Besser and Miller (2004) claimed that the business efforts leading to the betterment of the community have both negative and positive results. This means that providing support for the community is not a guaranteed formula for business success (Besser, \& Miller, 2004). Based on these arguments, it is postulated that:

$\mathrm{H}_{5}$ : Place identity is positively related to support for community.

$\mathrm{H}_{6}$ : Support for community is positively related to SMTEs' performance.

$\mathrm{H}_{7}$ : Support for community mediates the relationship between place identity and SMTEs' performance.

Based on the above literature review and hypotheses, the following research model (Figure 1) was developed.

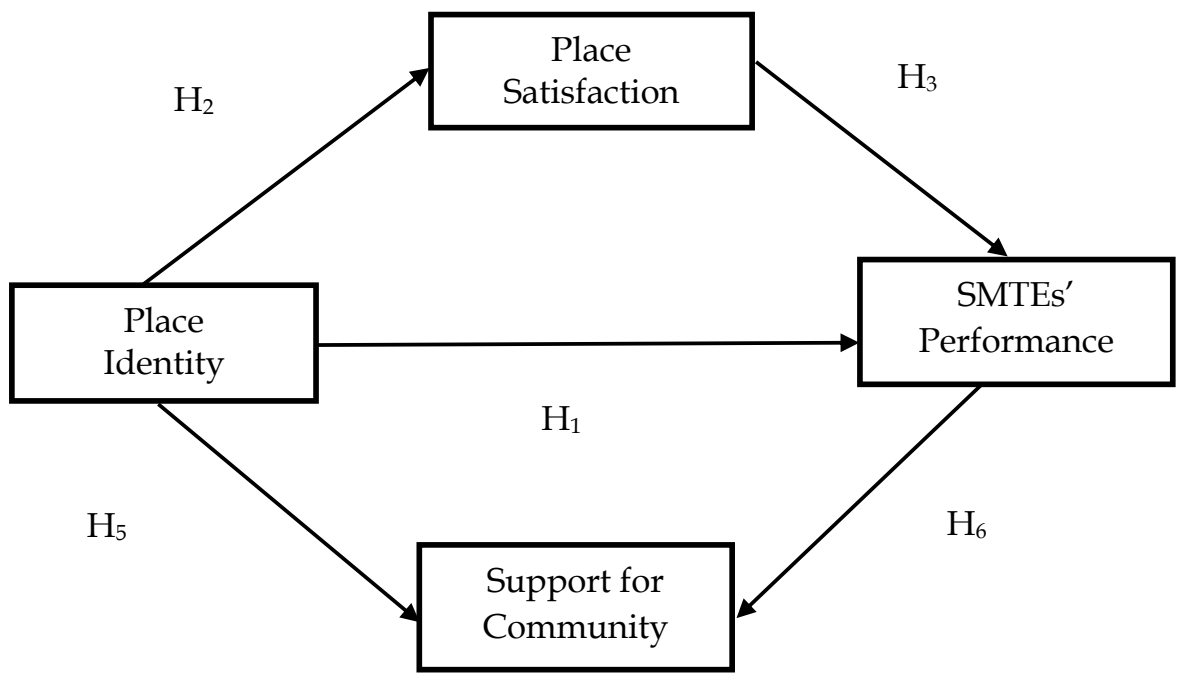

$\mathrm{H}_{4}$ and $\mathrm{H}_{7}$ represent the mediating relationship

Figure 1: Research Model

\section{Research Methodology}

A quantitative survey was carried out on SMTEs to test the research framework and hypotheses developed. Items used to measure each construct/variable were adapted from previous studies, for instance, place identity was measured using items adopted from Hallak et al. 
(2012). It covers the evaluative comparison between own place and others, its perceived uniqueness, and the general sense of belongingness. Three items were adapted from Ramkissoon et al. (2013) to measure place satisfaction, and five items were adopted from Hallak et al. (2013) to evaluate support for community. The SMTEs' performance was measured by using six items adopted from Hallak et al. (2014). A sixpoint Likert rating scale was used to measure the used items where $1=$ strongly disagree, and $6=$ strongly agree.

Cox's Bazar in Bangladesh was selected as the site and subject of this study. As a tourist destination, Cox's Bazar is one of the leading tourism destinations in Bangladesh. With a scenic beauty of $120 \mathrm{~km}$, the destination is recognised as the world's longest unbroken sandy beach. Thus, it is not surprising that this tourism spot receives more than 1.5 million tourists every year, which has led to the fast development of facilities, including hotels, restaurants, and gift shops (Bangladesh Tourism Board, 2016). The target population of this study comprises the SMEs or the small and medium tourism-based operations of Bangladesh, namely those with 99 or fewer employees. The samples were drawn from Bangladesh's Yellow Pages. Only businesses that were located in Cox's Bazar was selected. Since the tourism industry was not formally defined in the listing, we thus selected businesses that were in the categories of retail, lodging, restaurant, recreation, agri-tourism, arts and museum. As the target population of this study were the SMTEs, we then selected the owners of the businesses as the key respondents. Of the 450 questionnaires distributed to the samples, only 227 were obtained, and twelve questionnaires were discarded due to incomplete responses, resulting in a final response of 215 questionnaires. Following the suggested sample size of various scholars (Hoyle, 1995; Tabachnick \& Fidell, 2007), the sample size used in this study has thus fulfilled the minimum sample requirement, so as to perform the partial least squares structural equation modelling (PLS-SEM) for data analysis. It is important to note that participation in this survey was voluntary, and respondents' consent was obtained prior to the distribution of the questionnaires. Table 1 depicts the respondents' profiles.

As noted from Table 1, a majority of the SMTE owners were males $(69.3 \%)$ between the ages of 31 to 40 years old (31.6\%). Most had completed secondary school education (33.5\%), and only 10.2 per cent of the respondents have tertiary education. This is not surprising considering that many of the local communities were reported to be illiterate, and not willing to start a tourism-related business. Instead, 
Table 1: Respondents' Profiles

\begin{tabular}{|c|c|c|c|}
\hline Variables & & Frequency & Percentage \\
\hline \multirow[t]{6}{*}{ Age } & 18 to 20 years & 28 & 13.0 \\
\hline & 21 to 30 years & 47 & 21.9 \\
\hline & 31 to 40 years & 68 & 31.6 \\
\hline & 41 to 50 years & 35 & 16.3 \\
\hline & 51 to 60 years & 24 & 11.2 \\
\hline & Above 60 years & 13 & 6.0 \\
\hline \multirow[t]{2}{*}{ Gender } & Male & 149 & 69.3 \\
\hline & Female & 66 & 30.7 \\
\hline \multirow[t]{6}{*}{ Level of Education } & Primary & 69 & 32.1 \\
\hline & SSC & 72 & 33.5 \\
\hline & HSC & 34 & 15.8 \\
\hline & Graduation & 22 & 10.2 \\
\hline & Post-graduation & 13 & 6.0 \\
\hline & Others & 5 & 2.3 \\
\hline \multirow[t]{6}{*}{ Business Type } & Accommodation & 12 & 5.6 \\
\hline & Restaurant/Cafe & 36 & 16.7 \\
\hline & Tour Operator & 13 & 6.0 \\
\hline & General Shops/Souvenir/Gift & 77 & 35.8 \\
\hline & Fast-food & 35 & 16.6 \\
\hline & Others & 42 & 19.5 \\
\hline \multirow[t]{6}{*}{ No. of Employees } & 1 to 2 persons & 128 & 59.5 \\
\hline & 3 to 5 persons & 65 & 30.2 \\
\hline & 6 to 10 persons & 12 & 5.6 \\
\hline & 11 to 15 persons & 4 & 1.9 \\
\hline & 16 to 20 persons & 3 & 1.4 \\
\hline & More than 20 persons & 3 & 1.4 \\
\hline \multirow[t]{5}{*}{ Monthly Income } & Tk. 5,000 to 10,000 & 10 & 4.7 \\
\hline & Tk. 10,001 to 15,000 & 42 & 19.5 \\
\hline & Tk. 15,001 to 20,000 & 55 & 25.6 \\
\hline & Tk. 20,001 to 25,000 & 70 & 32.6 \\
\hline & Above Tk. 25,000 & 38 & 17.7 \\
\hline
\end{tabular}

they were more comfortable in taking up employment in hotels, restaurants and guesthouses (Islam \& Carlsen, 2012). Majority of the respondents operated a general/souvenir/gift shop (35.8\%), others $(19.5 \%)$, restaurant/cafe $(16.7 \%)$, and fast-food $(16.6 \%)$. More than half of the businesses employed 1 to 2 persons (59.5\%), and earned about 
Tk. 20001-25000 (32.6\%). This information shows that majority of the businesses were micro and small scale businesses.

\section{Analysis and Findings}

In this study, the partial least squares-based structural equation modelling (PLS-SEM) was applied to test the causal relations between the constructs of the proposed model. This analytical technique is more appropriate for a research of the exploratory and confirmatory nature as it aims to examine the extent of the relationship between the exogenous and endogenous constructs where independent constructs predict the ultimate dependent constructs (Hair, Hult, Ringle, \& Sarstedt, 2017; Ringle, Wende, \& Becker, 2015). This technique is increasingly applied in marketing research and other business units (Henseler, Ringle, \& Sinkovics, 2009). Prior to the hypotheses testing, a measurement model analysis was performed to evaluate the convergent and discriminant validity (Hair et al., 2017; Ringle et al., 2015).

\subsection{Measurement Model Analysis}

In assessing the measurement model, convergent validity was evaluated by examining the factor loadings, composite reliability, and average variance extracted (AVE) (Fornell \& Larcker, 1981). Table 2 presents the outcome of the convergent validity.

As can be noted from Table 2, the standardised factor loadings in the measurement model exceeded the recommended threshold value of 0.50 (Byrne, 2010; Hair, Anderson, Babin, \& Black, 2010). In addition, the composite reliability (CR) of all the constructs exceeded the recommended threshold value of 0.70 (Sarkar, Echambadi, \& Harrison, 2001). Likewise, as per the suggestions of Fornell and Larcker (1981), the AVE values of all the research constructs were above the recommended threshold value of 0.50 . Therefore, this study has satisfactorily fulfilled all the three conditions of the convergent validity.

The criteria recommended by Fornell and Larcker (1981) were used to test the discriminant validity. It had proposed that the square root of the AVE should exceed the correlation values between the constructs of the study. This is further highlighted in Table 3 where it can be seen that the square roots of the AVEs were greater than the correlation values for each research construct's pairing. Therefore, the test results of the discriminant validity were satisfactorily met. 
Table 2: Convergent Validity

\begin{tabular}{|c|c|c|c|c|c|c|}
\hline Construct & Item & Description & $\begin{array}{l}\text { Factor } \\
\text { Loading }\end{array}$ & $\alpha$ & CR & AVE \\
\hline & PI1 & Recognised as prestigious place & 0.64 & & & \\
\hline & PI2 & $\begin{array}{l}\text { This town has many advantages } \\
\text { compared to others }\end{array}$ & 0.78 & & & \\
\hline & PI3 & Not a great place to visit & 0.75 & & & \\
\hline Place & PI4 & Envied by people of other towns & 0.71 & & & \\
\hline \multirow{4}{*}{ Identity } & PI5 & Native feelings for this town & 0.83 & 0.84 & 0.89 & 0.68 \\
\hline & PI6 & Feel at home in this town & 0.86 & & & \\
\hline & PI7 & Town is like a part of oneself & 0.74 & & & \\
\hline & PI8 & Feel as a member of this town & 0.85 & & & \\
\hline Place & PS & Choosing this place is right & 0.83 & & & \\
\hline \multirow[t]{2}{*}{ Satisfaction } & PS2 & Satisfied by choosing this place & 0.85 & 0.83 & 0.90 & 0.75 \\
\hline & PS3 & Happy for this decision & 0.91 & & & \\
\hline \multirow{4}{*}{$\begin{array}{l}\text { Support for } \\
\text { Community }\end{array}$} & SC1 & Assist in community projects & 0.64 & \multirow{4}{*}{0.66} & \multirow{4}{*}{0.79} & \multirow{4}{*}{0.50} \\
\hline & SC3 & Provide financial assistance & 0.72 & & & \\
\hline & SC4 & $\begin{array}{l}\text { Community festivals and events } \\
\text { involvement }\end{array}$ & 0.69 & & & \\
\hline & SC5 & $\begin{array}{l}\text { Assistance environment } \\
\text { protection project }\end{array}$ & 0.72 & & & \\
\hline \multirow{6}{*}{$\begin{array}{l}\text { SMTEs' } \\
\text { Performance }\end{array}$} & EP1 & Business has been very profitable & 0.55 & \multirow{6}{*}{0.88} & \multirow{6}{*}{0.91} & \multirow{6}{*}{0.64} \\
\hline & EP2 & Generated a high volume of sales & 0.76 & & & \\
\hline & EP3 & Achieved rapid growth & 0.86 & & & \\
\hline & EP4 & Performance has been satisfactory & 0.84 & & & \\
\hline & EP5 & Business has been very successful & 0.86 & & & \\
\hline & EP6 & Business fully met expectations & 0.89 & & & \\
\hline
\end{tabular}

Table 3: Results of the Discriminant Validity

\begin{tabular}{lcccc}
\hline Variables & PI & PS & SC & SP \\
\hline Place Identity (PI) & $\mathbf{0 . 7 2}$ & & & \\
Place Satisfaction (PS) & 0.40 & $\mathbf{0 . 8 0}$ & & \\
Support for Community (SC) & 0.49 & 0.22 & $\mathbf{0 . 8 2}$ & \\
SMTEs' Performance (SP) & 0.10 & 0.20 & 0.18 & $\mathbf{0 . 6 9}$
\end{tabular}

Note: Bold diagonal values represent the square root of the AVE; the off-diagonal values represent the correlation coefficient. 


\subsection{Structural Model Analysis}

The SmartPLS-3.0 was used to assess the structural model while the path coefficients of the relationship between the latent constructs were tested using the bootstrapping technique (Hair et al., 2017; Ringle et al., 2015). A subsample of 5,000 was used to replace the original sample so as to determine the bootstrapping's standard error. It produced the appropriate $\mathrm{t}$-values for significance testing of the structural path (Hair, Ringle, \& Sarstedt, 2011). The critical value of the significance level for one-tailed test was different from the two-tailed test. This implied that the level of significance for the path coefficients should be at the minimum of 0.05 (Hair et al., 2017). The one-tailed test showed that the critical values for significance were at $0.01,0.05$, and 0.10 , respectively (Hair et al., 2017).

Table 4 illustrates the model's individual path relationship where all the beta values and t-values were presented. The result showed that place identity had a positive and direct effect on SMTEs' performance $(\beta=0.20, t=2.69, p<0.01)$, place satisfaction $(\beta=0.39, t=5.09$, $\mathrm{p}<0.01)$, and support for community $(\beta=0.16, \mathrm{t}=2.27, \mathrm{p}<0.05)$. This finding supported $\mathrm{H}_{1}, \mathrm{H}_{2}$, and $\mathrm{H}_{5}$. The finding also showed that place satisfaction had a direct and positive relationship on SMTEs' performance $(\beta=0.42, \mathrm{t}=6.51, \mathrm{p}<0.01)$. Therefore, hypothesis $\mathrm{H}_{3}$ was also supported. This study, however, found no empirical evidence to support the relationship between support for community and SMTEs' performance $(\beta=0.10, t=1.31, p>0.05)$. Hence, $H_{6}$ was rejected.

Table 4: Results of the Path Coefficient and T-statistics

\begin{tabular}{ccccl}
\hline Hypotheses & $\begin{array}{c}\text { Path } \\
\text { Relationship }\end{array}$ & $\begin{array}{c}\text { Coefficient } \\
(\beta)\end{array}$ & T-Statistics & Results \\
\hline $\mathrm{H}_{1}$ & $\mathrm{PI} \rightarrow \mathrm{SP}$ & 0.20 & $2.69^{* * *}$ & Supported \\
$\mathrm{H}_{2}$ & $\mathrm{PI} \rightarrow \mathrm{PS}$ & 0.39 & $5.09^{* * *}$ & Supported \\
$\mathrm{H}_{3}$ & $\mathrm{PS} \rightarrow \mathrm{SP}$ & 0.42 & $6.51^{* * *}$ & Supported \\
$\mathrm{H}_{5}$ & $\mathrm{PI} \rightarrow \mathrm{SC}$ & 0.16 & $2.27^{* *}$ & Supported \\
$\mathrm{H}_{6}$ & $\mathrm{SC} \rightarrow \mathrm{EP}$ & 0.10 & 1.31 & Not Supported \\
\hline
\end{tabular}

Note: ${ }^{* * *} \mathrm{p}<0.01,{ }^{* *} \mathrm{p}<0.5$.

This study also examined the mediation effect of place satisfaction, and support for community on the relationship between owner's place identity and SMTEs' performance. The beta values and standard error 
values are presented in Table 5 which shows that place satisfaction significantly mediated the relationship between owner's place identity and tourism enterprises' performance, since it does not straddle a 0 (zero) between the lower and upper levels. Thus, $\mathrm{H}_{4}$ was supported. Nonetheless, the mediation hypothesis of support for community did not mediate the relationship between owner's place identity and tourism enterprises' performance as it straddled a 0 (zero). Therefore, hypothesis $\mathrm{H}_{7}$ was rejected.

Table 5: Results of the Mediation Effect

\begin{tabular}{ccccccl}
\hline Hypotheses & Paths & $\begin{array}{c}\text { Coeffi- } \\
\text { cient }(\beta)\end{array}$ & SE & LLCI & ULCI & Results \\
\hline $\mathrm{H}_{4}$ & $\mathrm{PI} \rightarrow \mathrm{PS} \rightarrow \mathrm{EP}$ & 0.16 & 0.04 & .073 & .258 & Supported \\
$\mathrm{H}_{7}$ & $\mathrm{PI} \rightarrow \mathrm{SC} \rightarrow \mathrm{EP}$ & 0.02 & 0.07 & -.004 & .063 & Not Supported \\
\hline
\end{tabular}

\section{Discussion}

This study has investigated the relationship between place identity, support for community, place satisfaction, and SMTEs' performance. The outcome derived from this study demonstrated that place identity and place satisfaction served as crucial factors in enhancing the SMTEs' performance of small scale businesses in the tourism industry in Bangladesh. This result is consistent with the place identity theory (Proshansky et al., 1983) and in line with a few past studies (Fleury-Bahi et al., 2008; Ramkissoon et al., 2013).

Originating from a country that is struggling with its economic emancipation since independence, most of the SMTE owners of Cox's Bazar had little knowledge about the tourism sector (Islam \& Carlsen, 2016). This inadequacy was expected to limit their abilities to grow. Nevertheless, the level of emotional and social links that the owners developed through their attachment and personal experiences with the place may help them to cope with the difficulties since place identity fitted with the owners' identity. The operating hotels, restaurants, and guesthouses in the area of Cox's Bazar, for instance, require the SMTEs to be familiar with the local markets. This is because they need to establish a direct business relationship with the suppliers, and to secure a continuous supply of fresh agricultural products with a good price. With the existence of intermediaries, many of which are from other 
areas in the market, the local people have limited access to the tourismbusinesses, hence, they would be less capable of maximising the profits (Islam \& Carlsen, 2016). Therefore, it is not surprising that a higher level of place identity would lead to higher business performance.

From the descriptive results noted, it appears that the owners of the tourism businesses in Cox's Bazar have a moderate to high level of attachment to the place. This factor may contribute to their positive perception and confidence of Cox's Bazar as a tourist destination, hence it may also be the plausible reason for them to play an active role in developing the place. They would be likely to invest their own resources, such as money and time in the activities of the place, and in turn, support the tourism development thereby bringing more economic benefits to the SMTEs themselves. To date, the tourism development of Cox's Bazar has not been well supported by the government (Mawa, 2020), as can be noted in the low quality local infrastructure. The tourism city suffers from indecent public transportation, and unsafe and insecure roads. These outcomes have, to some extent, dampened the growth of the tourism sector. In the absence of government support, the sense of belonging and attachment of the SMTE owners for the tourism site has further encouraged them to play an active role in providing good tourism service, as they value the place highly. This factor could be the plausible reason supporting the importance of place satisfaction as a mediator.

In this study, the impact of place identity on support for community was established. This finding supports previous empirical work (Lewicka, 2005). SMTE owners who were attached to the place would ultimately become involved in activities that support and benefit their local community. Establishing a tourism business in the first place, has created employment opportunities for the local people, offering especially, the poor and marginal households to engage themselves suitably somewhere in the local tourism sector. Differing from previous studies (Hallak et al., 2012), this study was only able to provide some insubstantial evidence to support the mediating role of support for community on the relationship between place identity and SMTEs' performance. This outcome is possibly caused by the lack of transparency in their philanthropic activities. Apart from this, the level of support for community provided by the SMTEs may not be sufficient to meet the demands of the local people, hence, ultimately it did not transfer into the SMTEs' performance. 


\section{Conclusion, Research Implications and Future Directions}

This study enriches the body of knowledge by offering evidence which helped to determine the mediating role of place satisfaction on the relationship between place identity and SMTEs' performance in the context of Bangladesh. The study emphasises on how factors, such as place identity, place satisfaction, and support for community, facilitated the small scale tourism operators to gain and sustain their performance. Such findings are important for these firms, since their growth is expected to bring socio-economic changes to the local community of Cox's Bazar.

The findings of this study may also benefit the owners of SMTEs who strived to attain business performance. These owners would gain more benefits if they developed feelings of belonging and a sense of place identity. Both these options have the potential to enhance their satisfaction, and willingness to optimise resources so as to achieve business goals. This study also provides an understanding of the role played by the locational characteristics of tourism. It was able to show that the physical qualities of a place may appear to offer a competitive advantage, the level of emotional connections, and the social relationships that helped to develop attachment would determine the sustainability of the SMTEs. The level of assessment that a place could offer, which is dependent on the emotional and psychological interactions, motivated them to acquire abilities to pursue and achieve their desired objective so as to ensure that the business is growing. The results of this study also showed that searching for social community support can have impactful economic gains. The support needs to foster the functional bonds and affective connections with the local community. In other words, in order to cultivate the link between support for community and business performance, initiatives and programmes need to be tailored so as to raise more positive perceptions, and to trigger people-place emotional and social connections. In this regard, the current study offers insights to tourism entrepreneurs, destination managers, tour operators and tourism investors to select business places that have a good identity towards stakeholders. It means that tourism entrepreneurs, who have special bonding with a particular tourism destination, may get more satisfaction in operating their business with the place that would ultimately lead to enterprise performance. Furthermore, entrepreneurs and investors ought to be more aware that support for community does not always improve 
enterprise performance, hence they should be more attentive in how they invest their money, effort and involvement for supporting the local community.

Apart from managerial contributions, this study also provides theoretical implications. It expands on previous literature by providing empirical evidence on the place identity theory. To the best of our knowledge, our study is also among the first to test a model that links place satisfaction with place identity and business performance. It expands on the previous empirical works conducted by Hallak et al. (2012), by suggesting that place satisfaction can serve as a route through which place identity is related to business performance amongst SMTEs.

In spite of the contributions of this study, the paper has identified two key limitations that may provide scope for future research. First, this research focusses solely on Cox's Bazar in Bangladesh. Thus, the results may not be generalised to other contexts that have different cultural, social and economic values. Second, the present study considered only three exogenous constructs (i.e. place identity, place satisfaction, and support for community) in understanding the factors influencing the performance of STMEs. The inclusion of other constructs, for instance, self-efficacy was not considered. The inclusion, of self-efficacy as an intervening variable between place identity and enterprises performance in future studies may enrich the findings.

\section{References}

Bangladesh Tourism Board. (2016). Tourists statistics (Online). Retrieved from http://tourismboard.gov.bd/publications/statistics/

Besser, T.L. (2003). New economy businesses in rural, urban, and metropolitan locations. Rural Sociology, 68(4), 531-553. http://dx.doi.org/10.1111/j.15490831.2003.tb00150.x

Besser, T.L., \& Miller, N.J. (2004). The risks of enlightened self-interest: Small businesses and support for community. Business \& Society, 43(4), 398-425. http://dx.doi.org/10.1177/0007650304271140

Budruk, M., Thomas, H., \& Tyrrell, T. (2009). Urban green spaces: A study of place attachment and environmental attitudes in India. Society and Natural Resources, 22(9), 824-839. http://dx.doi.org/10.1080/08941920802628515

Byrne, B.M. (2010). Multivariate applications series. Structural equation modeling with AMOS: Basic concepts, applications, and programming (2nd ed.). New York, NY: Routledge/Taylor \& Francis Group.

Chang, J. (2011). Introduction: Entrepreneurship in tourism and hospitality: The role of SMEs. Asia Pacific Journal of Tourism Research, 16(5), 467-469. http:/ / dx.doi.org/10.1080/10941665.2011.597572 
Chen, S., Wang, S., \& Xu, H. (2017). Influence of place identity on residents' attitudes to dark tourism. Journal of China Tourism Research, 13(4), 338-356. http:/ / dx.doi.org/10.1080/19388160.2017.1401023

Daniloska, N., \& Hadzi Naumova-Mihajlovska, K. (2015). Rural tourism and sustainable rural development. Economic Development, 17, 307-320.

Fornell, C., \& Larcker, D.F. (1981). Evaluating structural equation models with unobservable variables and measurement error. Journal of Marketing Research, 18(1), 39-50. http:/ / dx.doi.org/10.2307/3151312

Fleury-Bahi, G., Line-Félonneau, B., \& Marchand, D. (2008). Processes of place identification and residential satisfaction. Environment and Behavior, 40(5), 669-682. http:/ /dx.doi.org/10.1177/0013916507307461

Getz, D., Carlsen, J., \& Morrison, A. (2004). The family business in tourism and hospitality. Wallingford, U.K.: CAB International.

Grey, C., \& O'Toole, M. (2020). The placing of identity and the identification of place: "Place-Identity" in community lifeboating. Journal of Management Inquiry, 29(2), 206-219. http:/ / dx.doi.org/10.1177\%2F1056492618768696

Gu, H., \& C. Ryan (2008). Place attachment, identity and community impacts of tourism - the case of a Beijing hutong. Tourism Management, 29(4), 637-647. http:/ / dx.doi.org/10.1016/j.tourman.2007.06.006

Hair, J.J.F., Anderson, R.E., Babin, B.J., \& Black, W.C. (2010). Multivariate data analysis: A global perspective (Vol. 7). Upper Saddle River, NJ: Pearson.

Hair, J.F., Ringle, C.M., \& Sarstedt, M. (2011). PLS-SEM: Indeed a silver bullet. Journal of Marketing Theory and Practice, 19(2), 139-152. http://dx.doi. org/10.2753/MTP1069-6679190202

Hair, J.F., Hult, G.T.M., Ringle, C. \& Sarstedt, M. (2017). A primer on partial least squares structural equation modeling (PLS-SEM). Thousand Oaks, CA: Sage Publications.

Hallak, R., Brown, G., \& Lindsay, N.J. (2012). The place identity-performance relationship among tourism entrepreneurs: A structural equation modelling analysis. Tourism Management, 33(1), 143-154. http://dx.doi.org/10.1016/j. tourman.2011.02.013

Hallak, R., Brown, G., \& Lindsay, N.J. (2013). Examining tourism SME owners' place attachment, support for community and business performance: The role of the enlightened self-interest model. Journal of Sustainable Tourism, 21(5), 658-678. http:/ / dx.doi.org/ 10.1080/09669582.2012.709861

Hallak, R., Assaker, G., \& O'Connor, P. (2014). Are family and nonfamily tourism businesses different? An examination of the entrepreneurial self-efficacyentrepreneurial performance relationship. Journal of Hospitality $\mathcal{E}$ Tourism Research, 38(3), 388-413. http:/ / dx.doi.org/10.1177/1096348012461545

Hallak, R., Assaker, G., \& Lee, C. (2015). Tourism entrepreneurship performance: The effects of place identity, self-efficacy, and gender. Journal of Travel Research, 54(1), 36-51. http:/ /dx.doi.org/ 10.1177/0047287513513170

Henseler, J., Ringle, C.M., \& Sinkovics, R.R. (2009), The use of partial least squares path modeling in international marketing. In Sinkovics, R.R. \& 
Ghauri, P.N. (Eds.) New Challenges to International Marketing (Advances in International Marketing, Vol. 20), Bingley: Emerald Group Publishing Limited, pp. 277-319. https://doi.org/10.1108/S1474-7979(2009)0000020014 Hmieleski, K.M., \& Corbett, A.C. (2008). The contrasting interaction effects of improvisational behavior with entrepreneurial self-efficacy on new venture performance and entrepreneur work satisfaction. Journal of Business Venturing, 23(4), 482-496. http:/ / dx.doi.org/10.1016/j.jbusvent.2007.04.002

Hidalgo, M.C., \& Hernandez, B. (2001). Place attachment: Conceptual and empirical questions. Journal of Environmental Psychology, 21(3), 273-281. http:/ /dx.doi.org/10.1006/jevp.2001.0221

Hoyle, R.H. (1995). Structural equation modeling: Concepts, issues, and applications, Thousand Oaks, CA: SAGE Publications, Inc.

Indriastuti, H., Kasuma, J., Saida Zainurrosalamia, Z.A., Darma, D.C. \& Sawangchai, A. (2020). Achieving marketing performance through acculturative product advantages: The case of Sarong Samarinda. Asian Journal of Business $\mathcal{E}$ Accounting, 13(1), 241-262. http:/ / dx.doi.org/10.22452/ajba.vol13no1.9

Islam, F. \& Carlsen, J. (2012). Tourism in Rural Bangladesh: Unlocking Opportunities for Poverty Alleviation? Tourism Recreation Research, 37(1), 3745. http://dx.doi.org/10.1080/02508281.2012.11081686

Islam, F., \& Carlsen, J. (2016). Indigenous communities, tourism development and extreme poverty alleviation in rural Bangladesh. Tourism Economics, 22(3), 645-654. http:/ / dx.doi.org/10.5367\%2Fte.2014.0456

Karim, M.R. (2014). Policy analysis of tourism development in Bangladesh compared with the Bhutanese policy. Journal of Public Administration and Policy Research, 6(6), 132-143. http:/ / dx.doi.org/10.5897/JPAPR2014.0246

Lewicka, M. (2005). Ways to make people active: The role of place attachment, cultural capital, and neighborhood ties. Journal of Environmental Psychology, 25, 381-395. https:// doi.org/10.1016/j.jenvp.2005.10.004

Mawa, J. (2020). Factors influencing tourists satisfaction based on service attributes of hotels: A study on Cox's Bazar, Bangladesh. Journal of Business Management and Accounting, 9(1), 27-54. http://dx.doi.org/10.32890/ jbma2019.9.1.8744

Miller, N.J., \& Besser, T.L. (2000). The importance of community values in small business strategy formation: Evidence from rural Iowa. Journal of Small Business Management, 38(1), 68-85.

Obst, P.L., \& White, K.M. (2005). An exploration of the interplay between psychological sense of community, social identification and salience. Journal of Community E Applied Social Psychology, 15(2), 127-135. http:// dx.doi.org/ 10.1002/casp.813

Proshansky, H.M., Fabian, A.K., \& Kaminoff, R. (1983). Place-identity: Physical world socialization of the self. Journal of Environmental Psychology, 3(1), 5783. http:/ / dx.doi.org/10.1016/S0272-4944(83)80021-8

Ramkissoon, H., Smith, L.D.G., \& Weiler, B. (2013). Testing the dimensionality of place attachment and its relationships with place satisfaction and 
pro-environmental behaviours: A structural equation modelling approach. Tourism Management, 36, 552-566. http://dx.doi.org/10.1016/j. tourman.2012.09.003

Ray, R. (2019). Micro and small enterprises involvement in pro-poor tourism: Evidence from Bangladesh (Doctoral dissertation, Curtin University).

Relph, E.C. (1976). Place and placelessness. London: Pion.

Ringle, C.M., Wende, S., \& Becker, J.M. (2015). SmartPLS 3. Hamburg, Germany: Bönningstedt.

Rogerson, C.M. (2005). Unpacking tourism SMMEs in South Africa: structure, support needs and policy response. Development Southern Africa, 22(5), 623642. http:/ / dx.doi.org/ 10.1080/03768350500364224

Sarkar, M.B., Echambadi, R.A.J., \& Harrison, J.S. (2001). Alliance entrepreneurship and firm market performance. Strategic Management Journal, 22(6-7), 701-711. http://dx.doi.org/10.1002/smj.179

Schilar, H., \& Keskitalo, E.C.H. (2018). Tourism activity as an expression of place attachment-place perceptions among tourism actors in the Jukkasjärvi area of northern Sweden. Scandinavian Journal of Hospitality and Tourism, 18(sup1), 42-59.http://dx.doi.org/10.1080/15022250.2017.1389123

Stedman, R.C. (2002). Toward a social psychology of place: Predicting behavior from place-based cognitions, attitude, and identity. Environment and Behavior, 34(5), 561-581. http://dx.doi.org/10.1177/0013916502034005001

Stets, J.E. \& Biga, C.F. (2003). Bringing identity theory into environmental sociology. Sociological Theory, 21(4), 398-423.

Tabachnick, B.G., \& Fidell, L.S. (2007). Using multivariate statistics. New York, NY: Allyn \& Bacon/Pearson Education.

Twigger-Ross, C.L., \& Uzzell, D.L. (1996). Place and identity processes. Journal of Environmental Psychology, 16(3), 205-220. http://dx.doi.org/10.1006/ jevp.1996.0017

WTTC. (2018). Power and performance ranking report. Retrieved from https://wttc. org/ 
